Annals of Warsaw University of Life Sciences - SGGW

Land Reclamation No 40, 2008: 87-96

(Ann. Warsaw Univ. of Life Sci. - SGGW, Land Reclam. 40, 2008)

\title{
The use of resistivity and seismic cone penetration tests for site characterization
}

\author{
MARIUSZ LECH, MAREK BAJDA, KATARZYNA MARKOWSKA-LECH \\ Department of Geotechnical Engineering, Warsaw University of Life Sciences - SGGW
}

\begin{abstract}
The use of resistivity and seismic cone penetration tests for site characterization. Recent application of cone penetration tests to geotechnical and environmental site characterization has generated a wide collection of new sensors. This paper presents methods of interpreting geotechnical in situ investigations carried out by electrical resistivity (RCPT) and seismic (SCPT) cones. It contains some fundamental equations and the description of in situ electrical resistivity and shear wave velocity measurements and presents the results of SCPT and RCPT investigations at the experimental Stegny site in Warsaw. The aim of the paper is to present the approach to determination of shear wave velocity and porosity of clayey soils. According to the test results obtained, it can be concluded that both applied techniques are very useful to estimate the distribution of clay deposits and some of their geotechnical parameters.
\end{abstract}

Key words: RCPT, SCPT, electrical resistivity, shear wave velocity, porosity.

\section{INTRODUCTION}

A great demand for in situ tests to assess geotechnical and environmental parameters caused evolution of CPTU measuring sensors. Modern CPTU cones (e.g. Envirocone, Chemoprobe, Visioncone, RCPT, SCPT, LIF) include sensors for determination of soil moisture content, temperature, $\mathrm{pH}$, dielectric constant, electrical resistivity and seismic wave velocities (Campanella et al. 1986, Olie et al. 1992, Pluimgraaff et al. 1995,
Hryciw and Raschke 1997, Lunne et al. 1997). Mentioned devices can be very useful in urban areas, waste disposal and contaminated sites for proper design of engineering structures and contamination transport modelling.

This paper presents the results of electrical resistivity (RCPT) and seismic (SCPT) tests carried out at the site in Warsaw. Geophysical methods have been applied to soil sciences for a considerable period and the addition of seismic and resistivity measurements during standard CPTU gives information about soil parameters in details (Campanella and Weemees 1990, Robertson 2001, Mayne and Campanella 2005). The use of resistivity module in RCPT test permits to evaluate groundwater quality (contamination), soil porosity and saturation. The seismic measurements added to SCPT cone allow to measure compression and shear wave velocities.

\section{TEST PROCEDURES AND EQUIPMENT}

There are several kinds of geophysical tests that can be used for geological, geotechnical and environmental applications including surface analysis of seismic waves (SASW), electrical resistivity and electromagnetic met- 
hods. Recently, the most developing techniques which are represented by combination of standard geotechnical tests with geophysical module have been used in the field. The combination of standard penetration tests and seismic measurements and electrical resistivity module has made a significant improvement to the CPTU test. The measurement of shear wave velocity using SCPT seismic cone (Fig. 1a) enables to obtain the initial shear modulus of soil at very small strain level, less than $0.0001 \%$. The knowledge about it is important in practical geotechnical solutions especially in earthquake engineering and in prediction of soil structure interaction (LoPresti et al. 1999, Bajda 2002, Stokoe et al. 2005, Markowska-Lech 2006). Elastic wave theory relates the small strain shear modulus $\left(G_{0}\right)$ using:

$$
G_{0}=\rho \cdot V_{s}^{2}
$$

where:

$G_{0}$ - initial shear modulus [MPa], $\rho-$ soil mass density $\left[\mathrm{Mg} / \mathrm{m}^{3}\right]$,

$V_{s}$ - shear wave velocity $[\mathrm{m} / \mathrm{s}]$.

During standard cone penetration test the following parameters are usually measured: cone resistance $\mathrm{q}_{\mathrm{c}}$, sleeve friction resistance $f_{s}$ and pore pressure u. The SCPT cone is additionally equipped with two geophones located in the distance of $1 \mathrm{~m}$ which permit to measure shear wave velocity in onemeter layer. During each SCPT test the cone penetration is stopped every $1 \mathrm{~m}$ and from the ground surface shear wave is generated. When the impulse arrives to the upper geophone, the oscilloscope starts and the impulse which is running to the lower geophone is being recorded (Fig. 1b). The travel time obtaining from the oscilloscope readings and the distance between geophones allow to estimate the shear wave velocity from:

$$
V_{s}=\frac{h}{t}
$$

where:

$V_{s}$ - shear wale velocity $[\mathrm{m} / \mathrm{s}]$,

$\mathrm{h}$ - distance between geophones [m] (in case of SCPT cone $\mathrm{h}=1.0 \mathrm{~m}$ ),

$t$ - travel time from 1st (upper) to the 2nd (lower) geophone [s].

The electrical resistivity of soils is a function of a number of soil properties, including mineralogy, particle size distribution, porosity (intergranular and fracture), water content, degree of saturation, salt concentration of the pore fluid and temperature. These parameters affect the electrical resistivity, but in different ways and to different extents (Keller and Frischknecht 1966, AbuHassanein et al. 1996, Lech, 2006). Soils, unconsolidated sediments and rocks are principally composed of silicate minerals, which are electrical insulators and they carry no current. The air medium is an insulator too and the current is mainly carried by ions in pore solutions. In most porous materials there is an empirical relationship established by Archie (1942), between the ratio of the bulk and pore fluid resistivity (called the formation factor) and the porosity. The relationship, called Archie's law is:

$$
F=\frac{\rho_{b S A T}}{\rho_{f}}=a \cdot n^{-m}
$$

where:

$F$ - formation factor [-], 


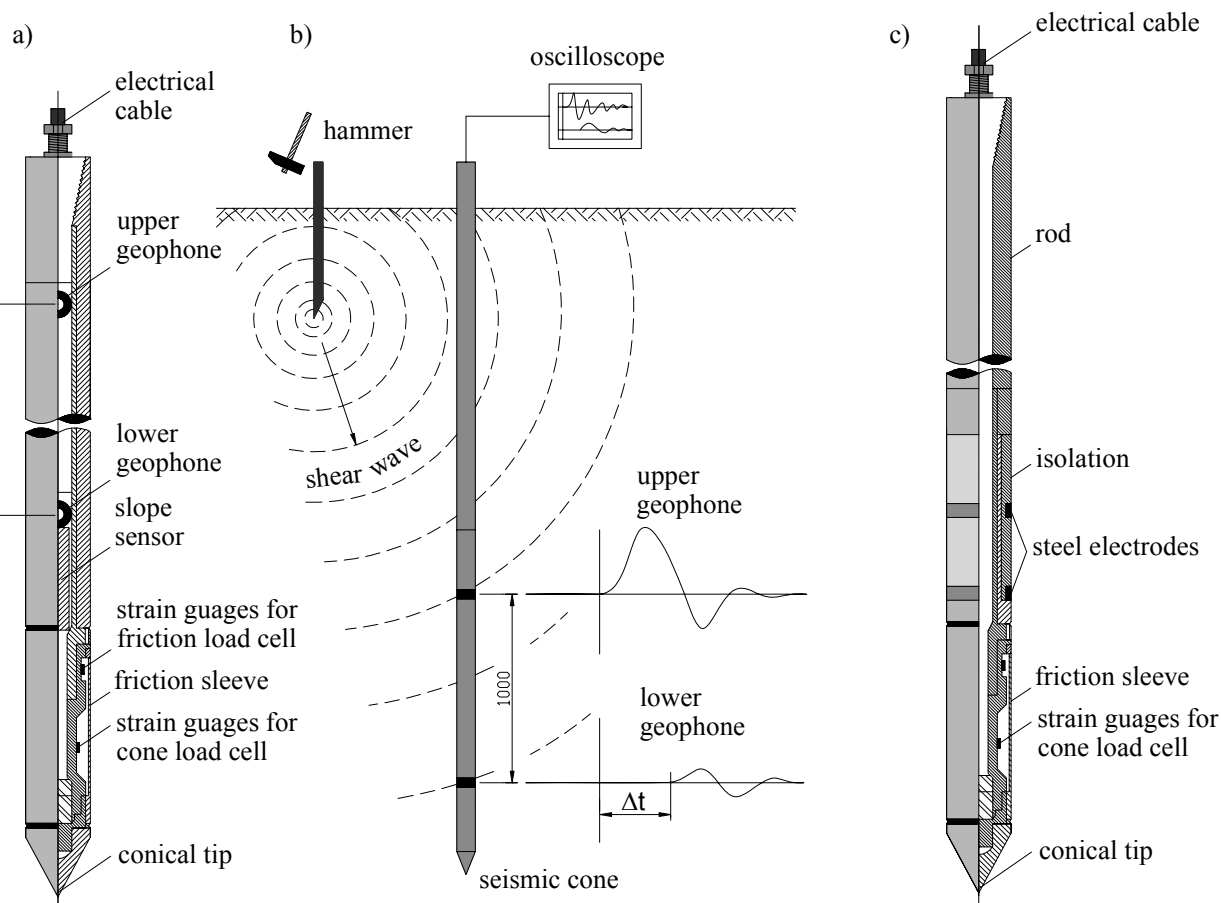

FIGURE 1. The SCPT seismic cone (a) with schematic diagram of shear wave measurements (b) and RCPT resistivity cone (c)

$\rho_{b S A T}$ - electrical resistivity of soil in fully saturated conditions $[\Omega \cdot \mathrm{m}]$, $\rho_{f}$ - electrical resistivity of fluid in pore spaces $[\Omega \cdot \mathrm{m}]$, $n$ - porosity [-],

a, $\mathrm{m}$ - empirical constants ("a" in most cases is equal to 1 ; "m" varies between 1.4 for quartz sand and 3.0 for sodium montmoryllonite (Atkins and Smith 1961, Jackson et al. 1975)).

The RCPT resistivity cone (Fig. 1c) is equipped with a module made from two electrodes separated by insulators. The measuring system of the penetrometer enables registration of electrical conductivity $(\delta[\mathrm{S}]=1 / \mathrm{R}[\Omega])$ within the range from 0 to $400 \mathrm{mS}$. The measurement is carried out with $\mathrm{AC}$ current at the frequency level of $2000 \mathrm{~Hz}$. To determine soil electrical resistivity (in $\Omega \cdot \mathrm{m}$ ) the calibration tests was carried out in a chamber using different concentrations of potassium chloride solutions. The RCPT test results were recorded by TouchScreen data acquisition system.

\section{IN SITU INVESTIGATIONS}

The in situ tests were carried out at the experimental site located in the southern district of Warsaw in the Vistula river valley. The stratigraphy consists of Quaternary deposits developed as fine and medium dense sand layers of thicknesses not exceeding $7 \mathrm{~m}$, underlain by overconsolidated Pliocene clays. The free groundwater table is at a depth of 
$3.2 \mathrm{~m}$ (Fig. 2). The index properties of clays at the Stegny site are listed in Table 1. Cone penetration tests (SCPT and RCPT) were carried out using $200 \mathrm{kN}$ hydraulic equipment in 10 profiles to the depth of about $15 \mathrm{~m}$.

\section{TEST RESULTS AND DISCUSSION}

In this paper selected results from in situ investigations are presented. Figure 3 presents the example of RCPT and SCPT test results in the form of continuous soil profiles of cone resistance $q_{c}$, friction

TABLE 1. Index properties of cohesive soils at the Stegny site

\begin{tabular}{|l|c|c|c|c|}
\hline Parameter & Unit & Clay & Silty clay & Clay \\
\hline depth & {$[\mathrm{m}]$} & $4.3-7.7$ & $7.7-8.9$ & $8.9-12$ \\
\hline fines content & {$[\%]$} & $68-80$ & $30-34$ & $32-46$ \\
\hline $\mathrm{W}_{\mathrm{n}}$ & {$[\%]$} & $26-34$ & $19-25$ & $19-27$ \\
\hline $\mathrm{LL}$ & {$[\%]$} & $77-98$ & $56-76$ & $86-110$ \\
\hline PI & {$[\%]$} & $52.6-76.4$ & $39.3-55.6$ & $61.9-84.0$ \\
\hline$\rho$ & {$\left[\mathrm{t} / \mathrm{m}^{3}\right]$} & $2.0-2.1$ & $2.0-2.4$ & $2.0-2.1$ \\
\hline
\end{tabular}

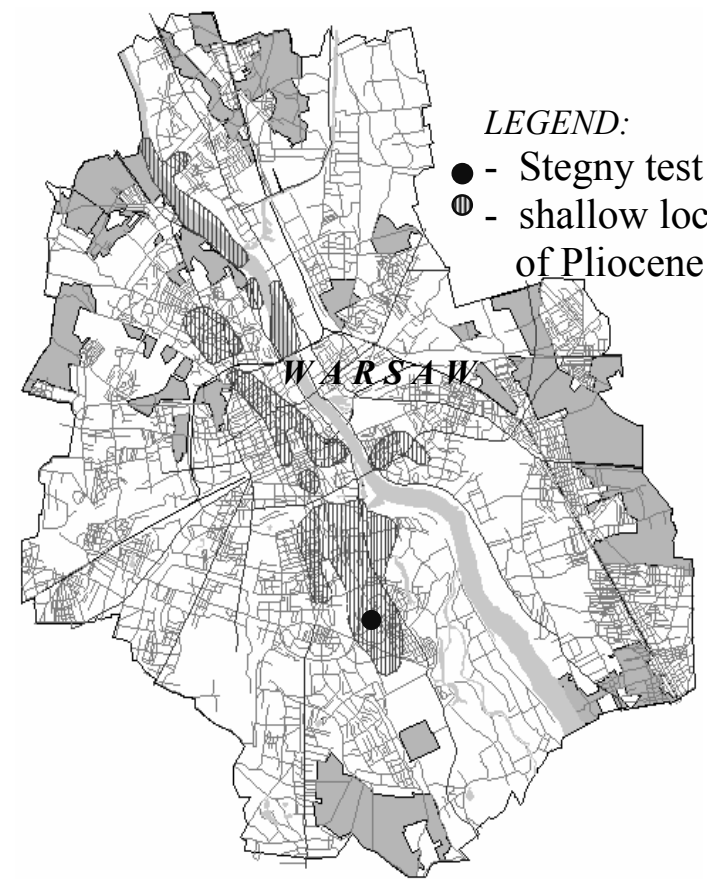

Borehole profile

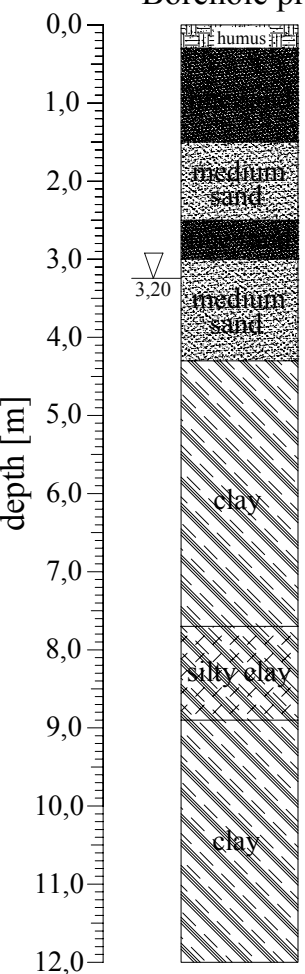

FIGURE 2. The location of the Stegny test site in Warsaw and borehole profile 

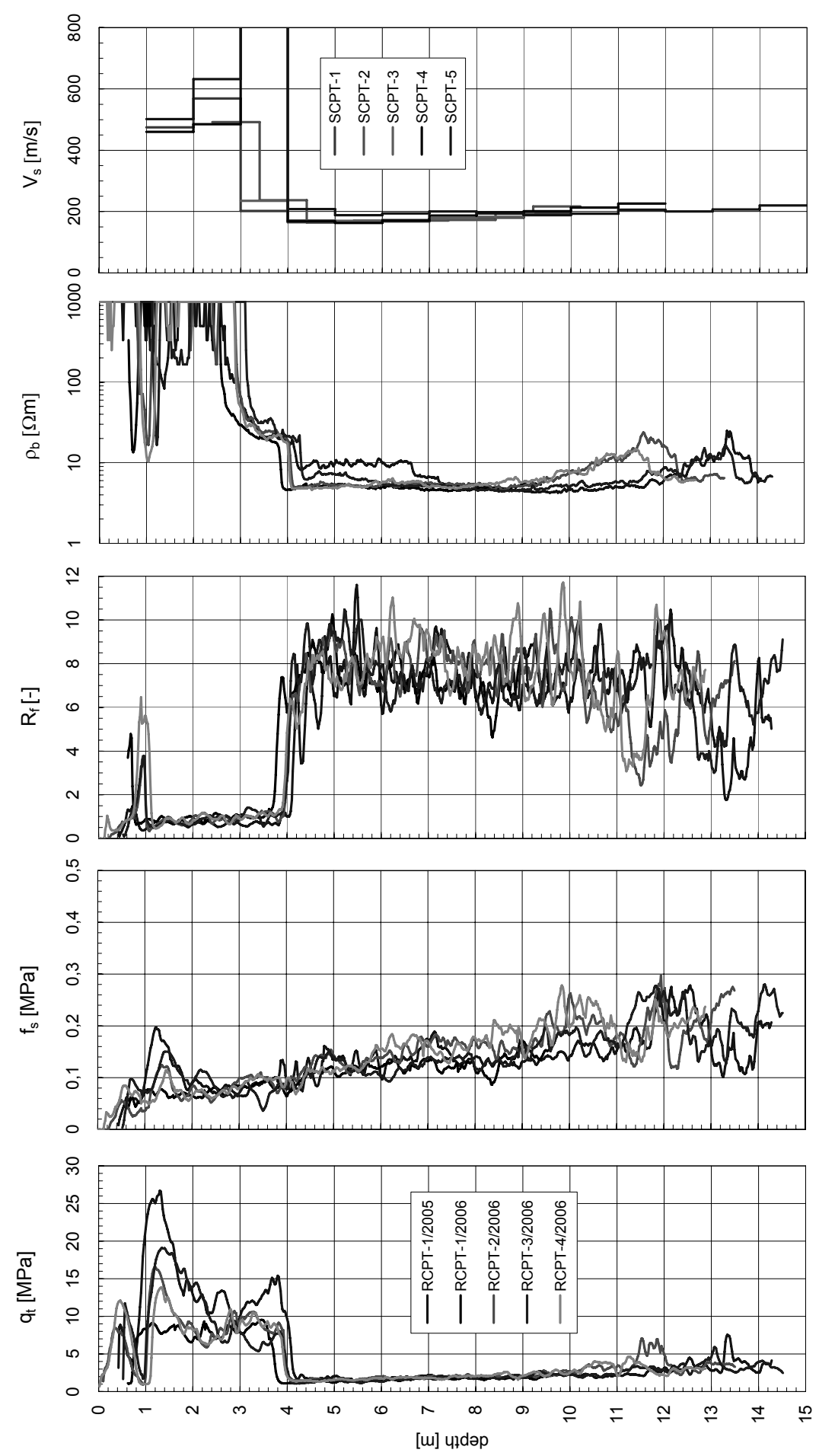
ratio $R_{f}$, sleeve friction resistance $f_{s}$, electrical resistivity $\rho_{b}$ and shear wave velocity $V_{s}$. There is a visible difference among sand and clay on these graphs. Values of cone resistance for sand vary from about $8 \mathrm{MPa}$ to $25 \mathrm{MPa}$ while for clays from $2 \mathrm{MPa}$ to $5 \mathrm{MPa}$. The type of soil can be classified using friction ratio $R_{f}$. It sharply increases from 1 to 8 at the depth of about $4.2 \mathrm{~m}$ and it separates sands and clays.

Similarly as cone resistance and friction ratio results, the resistivity and shearwavevelocity plotsshow differences between soil layers. In Figure 3 sands showed relatively higher resistivity values than clays. The presence of fine particles in clays, decrease the resistivity due to the presence of conducting clay minerals and the increase of specific surface area (in clayey soils electrical conduction takes place in the surfaces of electrically charged clayey minerals and it is known as a surface conduction). Values of electrical resistivity for sands are in range of about 100 and $1000 \Omega \cdot \mathrm{m}$ while in clays does not exceed $10 \Omega \cdot \mathrm{m}$.
Electrical resistivity in sands at the depth between 3 and $4.2 \mathrm{~m}$ is decreasing from the value from 100 to $20 \Omega \cdot m$ due to the influence of ground water table at the depth of $3.2 \mathrm{~m}$.

Observing Figure 3 there is a significant difference between values of shear wave velocity at the depth of about $4 \mathrm{~m}$ due to effect of soil type changes and influence of ground water table. Values of shear wave velocity in sands exceed $500 \mathrm{~m} / \mathrm{s}$ while in cohesive soils vary from 150 to $200 \mathrm{~m} / \mathrm{s}$ (Bajda 2002, Markowska-Lech et al. 2007). It was also noticed that resistivity plot correlates with shear wave velocity, cone resistance and friction ratio plots.

On the basis of field investigations simple and multiple regression analyses were performed with $\mathrm{V}_{\mathrm{s}}$ and $\mathrm{n}$ as the dependent parameters and independent parameters including $\mathrm{q}_{\mathrm{c}}, \mathrm{f}_{\mathrm{s}}, \sigma_{\mathrm{v} 0}^{\prime}$ LI and $\rho_{\mathrm{b}}$. The purpose of this analyses is to develop a correlation to estimate porosity (Fig. 4) and shear wave velocity (Fig. 5) in clays at Stegny site. Taking into account that clayey soils are fully

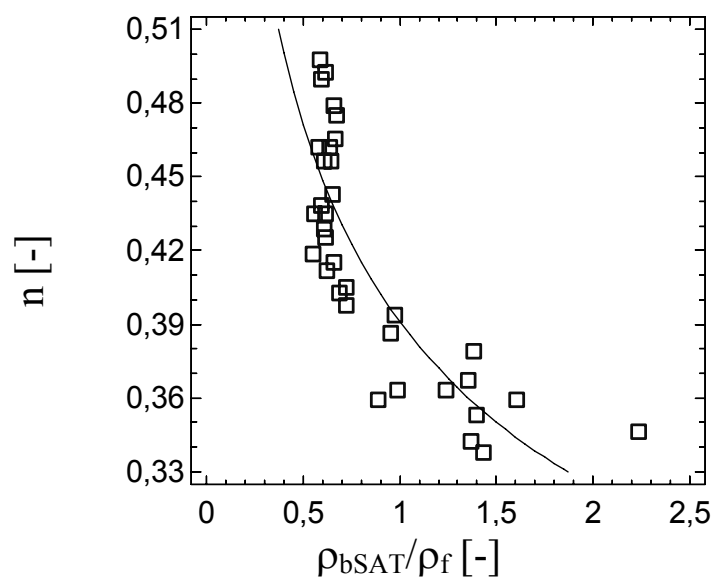

FIGURE 4. Relationship between porosity $\mathrm{n}$ and formation factor $\mathrm{F}\left(\rho_{\mathrm{bSAT}} / \rho_{\mathrm{f}}\right)$ 


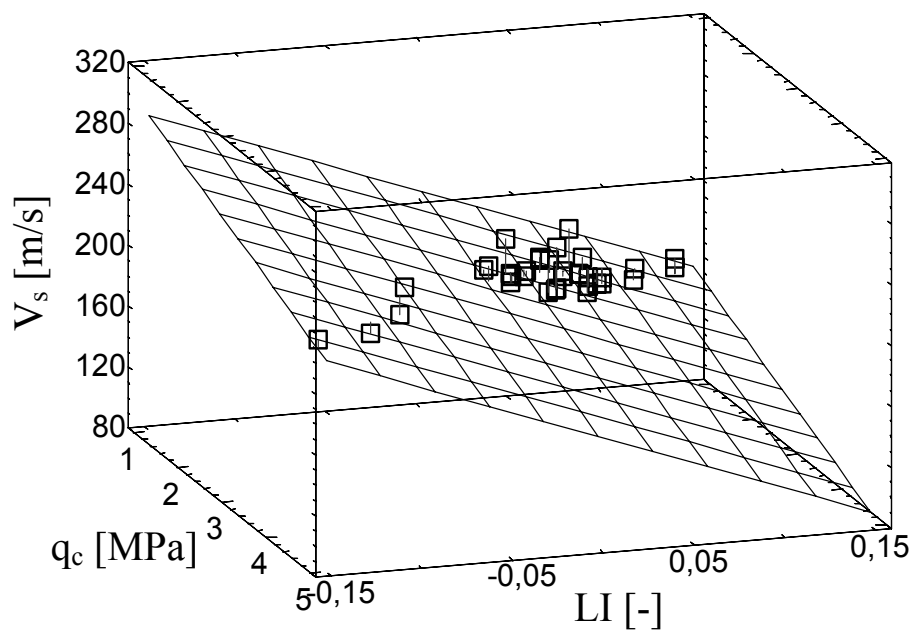

FIGURE 5. Relationship between shear vawe velocity $\mathrm{V}_{\mathrm{s}}$ and cone resistance $\mathrm{q}_{\mathrm{c}}$ and liquidity limit LI

saturated material and using Archie's formula we can write that porosity of clays at Stegny site is:

$$
n=0.39 \cdot\left(\frac{\rho_{b S A T}}{\rho_{f}}\right)^{-0.27} \quad\left(\mathrm{R}^{2}=69.9 \%\right)
$$

where:

$n$ - porosity [-],

$\rho_{b S A T}$ - electrical resistivity of soil in fully saturated conditions $[\Omega \cdot \mathrm{m}]$, $\rho_{f}$ - electrical resistivity of pore fluid measured by conductivity meter in laboratory $[\Omega \cdot \mathrm{m}]\left(\rho_{f}\right.$ was found to be 8.3 $\Omega \cdot \mathrm{m})$,

The second purpose is to give the estimation of $V_{S}$ in clays directly from standard cone penetration test. The shear wave velocity may be calculated according to the following equation:

$V_{s}=-17.15 \cdot q_{c}-429.26 \cdot \mathrm{LI}+239.36$

$\left(\mathrm{R}^{2}=65.6 \%\right)$

where:

$q_{c}-$ cone resistance [MPa],

LI - liquidity index [-].
This relationship may have practical meaning due to the possibility to determine initial shear modulus $\left(G_{0}\right)$ using standard cone penetration tests without geophones.

In order to verify proposed relationships, both porosity calculated according to proposed formula and obtained in laboratory tests (Baranski et al. 2004) were ploted in Figure 6. According to equation (4) and laboratory tests porosity in tested clays vary between 0.30 and 0.50 .

Figure 6 shows also changes of shear wave velocity based on SCPT tests and predicted from proposed relationship (5). The shear wave velocity both measured and predicted vary between 160 and 220 $\mathrm{m} / \mathrm{s}$. Comparing values from SCPT and predicted on the basis of cone resistance and liquidity index it can be noticed that they are similar and the velocity is growing with the depth. Moreover, observing Figure 6 it can be noticed that for the maximum value of porosity we have the minimum value of shear wave velocity. 


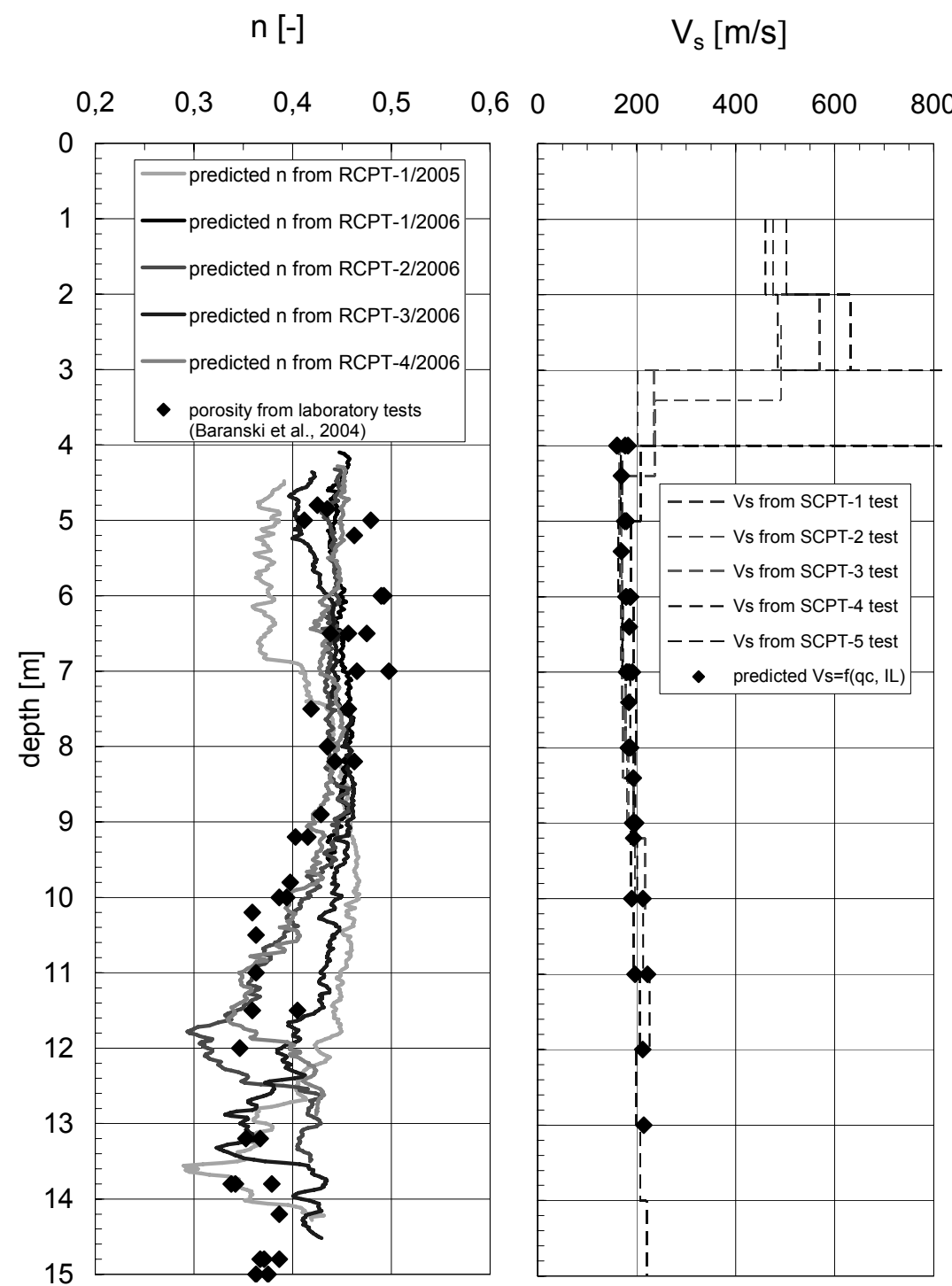

FIGURE 6. Measured and predicted values of porosity and shear wave velocity for clays at Stegny site

\section{CONCLUSIONS}

The RCPTU and SCPTU cones are a combination of standard geotechnical devices with geophysical modules. These tools provide a simple in situ testing methodology and give more reliable site characterization. In conclusion it can be drawn that the trend for measured porosity and shear wave velocity is similar to that proposed in this study. The most reliable method to obtain the shear wave velocity 
is the direct in situ measurements. The predicted porosity values using electrical resistivity method compared well with those measured in laboratory. Hence it can be concluded that the electrical measurements could predict porosity in clays. Proposed equations are still preliminary and needs more verification by being applied at different clay sites.

\section{REFERENCES}

ABU-HASSANEIN Z.S., BENSON C.H., BOLTZ L.R. 1996: Electrical resistivity of compacted clays. Journal of Geotechnical Engineering, vol. 122, No 5, 397-406.

ARCHIE G.E. 1942: The electrical resistivity $\log$ as an aid in determining some reservoir characteristics. Transactions of the American Institute of Mining and Metallurgical Engineers, vol. 146, 54-61.

ATKINS E.R., SMITH G.H. 1961: The significance of particle shape in formation resistivity factor - porosity relationships. Journal of Petroleum Technology, vol. 13, 285-291.

BAJDA M. 2002: The use of seismic cone penetration testing for estimation of mechanical parameters of soils. PhD thesis, Department of Geological Engineering, Warsaw Agricultural University - SGGW. (In Polish.)

BARANSKI M. ET AL. 2004: Behavior of Pliocene clays from the Stegny site in effective stress conditions. Grant 5T12B04122, Warsaw University. (In Polish.)

CAMPANELLA R.G., ROBERTSON P.K., GILLESPIE D. 1986: Seismic cone penetration test. Proceedings of the Special Conference In Situ'86. Use of In Situ Testing in Geotechnical Engineering. Blacksburg, Virginia, USA, 116-130.

CAMPANELLA R.G., WEEMEES I. 1990: Development and use of an electrical resistivity cone for groundwater contamination studies. Canadian Geotechnical Journal, vol. 27, No 5, 557-567.

HRYCIW R.D., RASCHKE S.A. 1997: Vision cone penetrometer for direct subsurface soil observation. Journal of Geoenvironmental Engineering, vol. 123, No 11, 1074-1076.

JACKSON P.D., TAYLOR SMITH D., STANFORD P.N. 1978: Resistivity porosity - particle shape relationships for marine sands. Geophysics, vol. 43, No 6, 1250-1268.

KELLER G.V., FRISCHKNECHT F.C. 1966: Electrical methods in geophysical prospecting. Pergamon Press, Oxford.

LECH M. 2006: The application of electrical resistivity method to recognize the ground water flow conditions. $\mathrm{PhD}$ thesis, Department of Geological Engineering, Warsaw Agricultural University-SGGW. (In Polish.)

LOPRESTI, D.C.F., PALLARA, O., JAMIOLKOWSKI, M., CAVALLARO, A. 1999: Anisotropy of small stiffness of undisturbed and reconstituted clays. Pre-failure Deformation of Geomaterials, Jamiolkowski, Lancellotta and LoPresti (eds), Balkema, Rotterdam: 3-10.

LUNNE T., ROBERTSON P.K., POWELL J.J. 1997: CPT in geotechnical practice. Blackie Academic and Professional.

MARKOWSKA-LECH K. 2006: Estimation of deformation parameters in cohesive soils using seismic tests, $\mathrm{PhD}$ thesis, Department of Geological Engineering, Warsaw Agricultural University-SGGW. (In Polish.)

MARKOWSKA-LECH K., LECH M., SZYMANSKI A. 2007: Estimation of shear moduluj from seismic tests on Pliocene clays. Numerical Models in Geomechanics NUMOG X. Taylor and Francis, Balkema: 153-158.

MAYNE, P.W., CAMPANELLA, R.G. 2005: Versatile site characterization by seismic piezocone. Proceedings of the 16th International Conference 
on Soil Mechanics and Geotechnical Engineering, Osaka 2005, Millpress, Rotterdam: 721-724.

OLIE J.J., VAN REE C.C.D.F., BREMMER C. 1992: In situ measurement by chemoprobe of groundwater from in situ sanitation of versatic acid spill. Geotechnique vol. 42, No 1, 13-21.

PLUIMGRAFF D., BRATTON W.L., HILHORST M. 1995: CPT sensors for bio-characterization of contaminated sites. Proceedings of International Symposium on Cone Penetration Testing, vol. 2, Linköping, 569-573.

ROBERTSON P.K. 2001: Sixty years of the CPT - How far have we come? International Conference on In situ Measurement of Soil Properties and Case Histories, Bali, 1-16.

STOKOE K.H.II, RATHJE E.M., AXTELL P.J. 2005: Development of an in situ method to measure the nonlinear shear modulus of soil. Proceedings of the 16th International Conference on Soil Mechanics andGeotechnicalEngineering, Osaka 2005, Millpress, Rotterdam: 751-754.

\section{LIST OF SYMBOLS}

$\mathrm{f}_{\mathrm{s}} \quad$ sleeve friction resistance

$\mathrm{F}$ formation factor

$\mathrm{G}_{0} \quad$ initial shear modulus

h distance between geophones

LI liquidity index

LL liquidity limit

n porosity

PI plsticity index

$\mathrm{q}_{\mathrm{c}} \quad$ cone resistance

$\mathrm{R}_{\mathrm{f}} \quad$ friction ratio

$\mathrm{t}$ time

$\mathrm{V}_{\mathrm{s}} \quad$ shear wave velocity

$\mathrm{w}_{\mathrm{n}} \quad$ natural water content

$\rho \quad$ soil mass density $\rho_{b} \quad$ electrical resistivity

$\rho_{\text {bSAT }}$ electrical resistivity in fully saturated conditions

$\rho_{\mathrm{f}} \quad$ electrical resistivity of fluid

$\delta \quad$ electrical conductivity

$\sigma^{\prime}{ }_{\mathrm{v} 0}$ horizontal stress in effective conditions

Streszczenie: Obecnie obserwuje się dynamiczny rozwój zastosowań badań geotechnicznych, w tym zwłaszcza sondowań, do oceny stanu środowiska. W związku z tym można zaobserwować zapotrzebowanie na specjalistyczne badania podłoża gruntowego, mogące pomóc w określeniu różnych parametrów stosowanych w geotechnice środowiskowej, takich jak np. temperatura gruntu, oporność elektryczna, odczyn $\mathrm{pH}$ gruntu, potencjał redoks i innych. W niniejszym artykule przestawione zostały wyniki sondowań geotechnicznych stożkiem wyposażonym w moduł do pomiaru oporności elektrycznej gruntu (RCPT) oraz stożkiem sejsmicznym (SCPT). W artykule przedstawiono podstawowe informacje na temat techniki badań, opis stosowanych urządzeń oraz wyniki badań na terenie poligonu badawczego na Stegnach w Warszawie. Celem pracy było określenie zależności empirycznych pomiędzy parametrami uzyskanymi z badań sondami RCPT oraz SCPT a porowatością i prędkością fali poprzecznej badanych gruntów spoistych. Na podstawie przeprowadzonych badań można wnioskować, że zastosowane urządzenia pozwalające na pomiar oporności elektrycznej i prędkości rozchodzenia się fali poprzecznej w gruncie mogą być z powodzeniem wykorzystane do rozpoznania budowy geologicznej podłoża i określania pewnych parametrów gruntu.

\section{MS. received November 2008}

\author{
Authors' address: \\ Mariusz Lech, Marek Bajda, Katarzyna \\ Markowska-Lech \\ Katedra Geoinżynierii \\ Wydział Inżynierii i Kształtowania Środowiska \\ - SGGW \\ 02-776 Warszawa 159 Nowoursynowska St. \\ mariusz_lech@sggw.pl
}

